九州大学学術情報リポジトリ

Kyushu University Institutional Repository

\title{
A Rapid Extraction - TLC Method for Differentiation of Burkholderia spp., Ralstonia solanacearum, Herbaspirillum rubrisubalbicans and Pseudomonas syringae Pathovars
}

Khan, Abu Ashuraf

Laboratory of Plant Pathology, Faculty of Agriculture, Kyushu University

Matsuyama, Nobuaki

Laboratory of Plant Pathology, Faculty of Agriculture, Kyushu University

https://doi.org/10.5109/24305

出版情報: 九州大学大学院農学研究院紀要. 44 (1/2)，pp.49-58，1999-11. Kyushu University バージョン：

権利関係 : 


\title{
A Rapid Extraction - TLC Method for Differentiation of Burkholderia spp., Ralstonia solanacearum, Herbaspirillum rubrisubalbicans and Pseudomonas syringae Pathovars
}

\author{
Abu Ashraf Khan and Nobuaki Matsuyama \\ Laboratory of Plant Pathology, Faculty of Agriculture, Kyushu University, \\ Fukuoka 812-8581, Japan
}

(Received July 19, 1999 and accepted August 24, 1999)

\begin{abstract}
8
A rapid extraction -TLC method was conducted for differentiation of Burkholderia spp. Ralstonia solanacearum, Herbaspirillum rubrisubalbicans and Pseudomonas syringae pathovars. Lipids were extracted from bacterial cells in a small glass-vial using $0.2 \mathrm{ml}$ of chloroform - methanol $-0.3 \% \mathrm{NaCl}$ solution $(2: 1: 0.4, \mathrm{v} / \mathrm{v} / \mathrm{v})$. The development of TLC plate was performed with chloroform - methanol $-0.2 \% \mathrm{CaCl}_{2} \cdot 2 \mathrm{H}_{2} \mathrm{O}$ solution $(55: 35: 8, \mathrm{v} / \mathrm{v} / \mathrm{v})$ for $1 \mathrm{~h}$ at $25^{\circ} \mathrm{C}$ and the amino-lipid spots were visualized by spraying ninhydrin and successive heating at $100^{\circ} \mathrm{C}$ for $10 \mathrm{~min}$. The chromatograms were characteristic at both the generic and spccies level. This method will be practical for rapid differentiation as well as identification of Burkholderia spp., R. solanacearum, H. rubrisubalbicans and $P$. syringae pathovars.
\end{abstract}

\section{INTRODUCTION}

Routine identification of phytopathogenic bacteria is generally conducted by a combination of physiolosical and biochemical tests. However, these tests are time consuming and require extensive experience to analyze the results. Therefore, the development of rapid methods has been emphasized. Both nucleic acid-based methodologies (Pecknold and Grogan, 1973; Bereswill et al., 1994) and chemotaxonomic methods (Ikemoto et al., 1978; De Boer and Sasser, 1986; Roy, 1988; Van Zyl and Steyn, 1990; Chase et al., 1992; Kori et al., 1992; Li and Hayward, 1994) have been used in bacterial taxonomy. However, these methods require expensive facilities. Though the lipid profiles have not been used widely, extensive research works show the potentiality of the method for the identification of bacteria. Matsuyama et al. (1986) developed the direct colony TLC (thin layer chromatography) method for the rapid detection and identification of bacterial lipids. Successful identification of phytopathogenic bacteria by this direct colony TLC method has been reported (Matsuyama et al., 1993a; Matsuyama and Furuya, 1993b; Matsuyama, 1995). However, the direct colony TLC method needs drying the bacterial colony on TLC plate before development. Furthermore, duplicated developments with two kinds of developing solvents are necessary. Recently, we modified the original method and then used the modified method for the identification of phytopathogenic bacteria (Khan and Matsuyama, 1998). We have continued to improve the method for lipid extraction process and the results are presented in this report. 


\section{MATERIALS AND METHODS}

\section{Bacterial strains}

Altogether 79 strains of Burkholderia spp., Ralstonia solanacearum, Herbaspirillum rubrisubalbicans and Pseudomonas syringae pathovars (all were formerly member of pseudomonads) were included in this experiment. The details of the strains are given in Table 1.

Table 1. List of Burkholderia spp., Herbaspirillum rubrisubalbicans, Raistonia solanacearum and Pseudomonas syringae pathovars used in this experiment.

\begin{tabular}{|c|c|c|c|}
\hline Bacteria & Isolate & & Source \\
\hline \multirow[t]{5}{*}{ B. caryophylli } & $\operatorname{ATCC} 25418^{\mathrm{T}}$ & & ATCC \\
\hline & NIAS 1192 & & NIAS \\
\hline & NLAS 1406 & & ", \\
\hline & MAFF 301060 & & NIAR \\
\hline & MAFF 302555 & & " \\
\hline \multirow[t]{4}{*}{ B. cepacia } & $\operatorname{ATCC} 25416^{\mathrm{T}}$ & & ATCG \\
\hline & $343-4$ & & NIAS \\
\hline & $356-3$ & & " \\
\hline & $356-5$ & & " \\
\hline \multirow[t]{9}{*}{ B. gladioli pv. gladioli } & ATCC 10248 & & ATCC \\
\hline & NIAS 1065 & & NIAS \\
\hline & $\mathrm{E}-14$ & & $\mathrm{AKU}$ \\
\hline & MAFF 302515 & & NIAR \\
\hline & MAFF 301064 & & " \\
\hline & MAFF 301580 & & " \\
\hline & MAFF 302385 & & " \\
\hline & MAFF 302537 & & " \\
\hline & MAFF 302544 & & " \\
\hline \multirow[t]{2}{*}{ B. gladioli pv. unidentified } & MAFF 302418 & & " \\
\hline & MAFF 302409 & & " \\
\hline$\cdot$ & MAFF 302424 & & " \\
\hline \multirow[t]{13}{*}{ B. glumae } & MAFF $301169^{\mathrm{T}}$ & & " \\
\hline & MAFF 302423 & & " \\
\hline & 2 & & KNAES \\
\hline & Kyu $82-34-2$ & & " \\
\hline & 8015 & & " \\
\hline & 8020 & & " \\
\hline & N 7401 & & NIAS \\
\hline & N 7501 & & " \\
\hline & N 7504 & & $"$ \\
\hline & N 7505 & & " \\
\hline & Ku 8104 & & $\mathrm{AKU}$ \\
\hline & $\mathrm{Ku} 8105$ & & " \\
\hline & Ки 8112 & & " \\
\hline \multirow[t]{6}{*}{ B. plantarii } & MAFF $301723^{r}$ & & NIAR \\
\hline & MAFF 302387 & & $"$ \\
\hline & MAFF 302484 & & $"$ \\
\hline & MAFF 302412 & $\cdot$ & $"$ \\
\hline & MAFF 302467 & & " \\
\hline & MAFF 302470 & & " \\
\hline
\end{tabular}


Continued Table 1

\begin{tabular}{|c|c|c|}
\hline Bacteria & Isolate & Source ${ }^{\text {a) }}$ \\
\hline & MAFF 302475 & NIAR \\
\hline & MAFF 302481 & " \\
\hline & MAFF 302485 & " \\
\hline & MAFF 302392 & " \\
\hline B. vandii & JCM $7957^{\top}$ & JCM \\
\hline \multirow{2}{*}{ B. andropogonis } & MAFF 301006 & NLAR \\
\hline & MAFF 301129 & " \\
\hline \multirow[t]{2}{*}{ H. mubrisubalbicans } & MAFF 301626 & " \\
\hline & MAFF 301628 & " \\
\hline \multirow[t]{9}{*}{ R. solanacearum } & ATCC $11696^{\mathrm{T}}$ & ATCC \\
\hline & C 319 & KTES \\
\hline & 8107 & NIVOT \\
\hline & 8224 & " \\
\hline & 6511 & NLAS \\
\hline & $\mathrm{Ku} 7502-1$ & $\mathrm{AKU}$ \\
\hline & 855 & UNB \\
\hline & $\mathrm{Z} 9$ & IPSA \\
\hline & $\mathrm{Z} 10$ & " \\
\hline P. syringae pv, syringae & $\operatorname{ATCC} 19310^{\mathrm{T}}$ & ATCC \\
\hline pv. oryzae & MAFF 301538 & NIAR \\
\hline pv. tabaci & PA 28 & KTES \\
\hline pv. tabaci & $\mathrm{P} 41$ & NLAS \\
\hline pv. tabaci & Ku 8102 & $\mathrm{AKU}$ \\
\hline pv. lachrymans & NIAS 1319 & NLAS \\
\hline pv. lachrymans & NIAS 1321 & " \\
\hline pv. mori & $\mathrm{P} 23$ & " \\
\hline pv. pisi & MAFF 301211 & NIAR \\
\hline pv. pisi & MAFF 301213 & " \\
\hline pv. theae & MAFF 750001 & $"$ \\
\hline pv. coronafaciens & MAFF 301314 & $"$ \\
\hline pv. phaseolicola & MAFF 301616 & " \\
\hline pv. phaseolicola & MAFF 301716 & $"$ \\
\hline pv. japonica & MAFF 301163 & " \\
\hline pv. atropurpurea & MAFF 301307 & " \\
\hline pv. morsprunomim & MAFF 301444 & $"$ \\
\hline pv. myricae & MAFF 301464 & $"$ \\
\hline pv. tomato & MAFF 301593 & " \\
\hline pv. glycinea & $\mathrm{KN} 28$ & NIAS \\
\hline pv. striafaciens & P 71 & , \\
\hline
\end{tabular}

a)ATCC: American Type Culture Collection, USA.

NIAS : National Institute of Agricultural Sciences, Tokyo, Japan.

NIAR: National Institute of Agrobiological Resources, Tsukuba, Japan.

AKU: Faculty of Agriculture, Kyushu University, Fukuoka, Japan.

KNAES: Kyushu National Agricultural Experiment Station, Kumamoto, Japan.

JCM: Japan Collection of Microorganisms, Saitama, Japan.

KTES: Kagoshima Tobacco Experiment Station, Japan.

NIVOT: National Research Institute of Vegetables, Ornamental Plants and Tea,

Morioka, Japan.

UNB: University of Brasilia, Brasilia, Brazil.

IPSA : Institute of Post Graduate Studies in Agriculture, Gazipur, Bangladesh.

Type culture: Small $\mathrm{T}$ at the shoulder of isolate number indicates type culture. 


\section{Growth conditions}

All bacterial strains were grown on slants of King's B agar medium (Eiken Chem. Co.). The medium consists of $20.0 \mathrm{~g}$ peptone, $1.5 \mathrm{~g} \mathrm{~K}_{3} \mathrm{HPO}_{4}, 1.5 \mathrm{~g} \mathrm{MgSO}_{4} \cdot 7 \mathrm{H}_{3} \mathrm{O}, 15.0 \mathrm{~g}$ agar and 1 litre of $1 \%$ glycerol solution, $\mathrm{pH} 7.2$. Slant cultures were grown at $30^{\circ} \mathrm{C}$ for 3 days.

\section{Lipid extraction}

One loopful bacterial cells was collected in a small glass vial from the slant culture and $0.2 \mathrm{ml}$ of chloroform - methanol $-0.3 \% \mathrm{NaCl}$ solution $(2: 1: 0.4, \mathrm{v} / \mathrm{v} / \mathrm{v})$ was added and the vial was capped tightly. Bacterial cells were suspended gently and kept at least for $15 \mathrm{~min}$ at room temperature.

\section{Thin layer chromatography}

Lipid extract (about $10 \mu \mathrm{l}$ ) was spotted on the origin of pre-coated silica gel TLC plate (Merck Co., Si 60, $0.25 \mathrm{~mm}$ in thickness) maintaining at a distance of $1.0 \mathrm{~cm}$ from the bottom edge of the plate and $1.5 \mathrm{~cm}$ from each other sample spots. The development of TLC plate was conducted in a rectangular glass tank with chloroform - methanol $0.2 \% \mathrm{CaCl}_{2} \cdot 2 \mathrm{H}_{2} \mathrm{O}$ solution $\left(55: 35: 8, \mathrm{v} / \mathrm{v} / \mathrm{v}\right.$ ) solvent system for $1 \mathrm{~h}$ at $25^{\circ} \mathrm{C}$. After development the TLC plate was dried well.

\section{Detection of lipid spots}

Lipid spots on TLC plate were detected by spraying ninhydrin (Ninhydrin spray, Tokyo Kasei Chem. Co.) followed by heating in an oven at $100^{\circ} \mathrm{C}$ for $10 \mathrm{~min}$. The chromatograms were recorded by photocopy, photograph and/or computer (Adobe photoshop 3.0 J).

\section{RESULTS}

Figures 1, 2 and 3 show the chromatographic profiles of lipids from Burkholderia spp., $R$. solanacearum, H. rubrisubalbicans and $P$. syringae pathovars. Lipid spots observed on TLC plate discriminate the strains at species level. The presence or absence and relative size of three benchmark spots designated as $S_{1}, S_{2}$, and $S_{3}$ (Figs. 1, 2 and 3) under the common spot ( $\mathrm{Rf} 0.76$ ) were species specific. The spot $\mathrm{S}_{2}$ was larger than spots $\mathrm{S}_{1}$ and $\mathrm{S}_{3}$ in $B$. caryophylli, whereas spot $\mathrm{S}_{1}$ was larger than $\mathrm{S}_{2}$ and $\mathrm{S}_{3}$ in case of $B$. cepacia. The chromatograms of B. gladioli, B. glumae, B. plantarii and B. vandii resembled each other. However, spot $S_{3}$ was found larger than $S_{1}$ and $S_{2}$ in $B$. plantarii and B. vandii (Figs. 1, 2 and 3).

The chromatograms of $B$. andropogonis and $R$. solanacearum were roughly similar at Rf $0.62-0.76$ area and spot $\mathrm{S}_{1}$ was absent. Spot $\mathrm{S}_{3}$ was absent or faint in $R$. solanacearum and different from $B$. andropogonis. The chromatograms of $H$. mibrisubalbicans and $P$. syringae pathovars were very special type, where spots $\mathrm{S}_{1}, \mathrm{~S}_{2}$ and $\mathrm{S}_{3}$ were not detected but a spot at $\mathrm{Rf} 0.83$ appeared in $H$. rubrisubalbicans along with the common spot at Rf 0.76 (Figs. 2 and 3). 


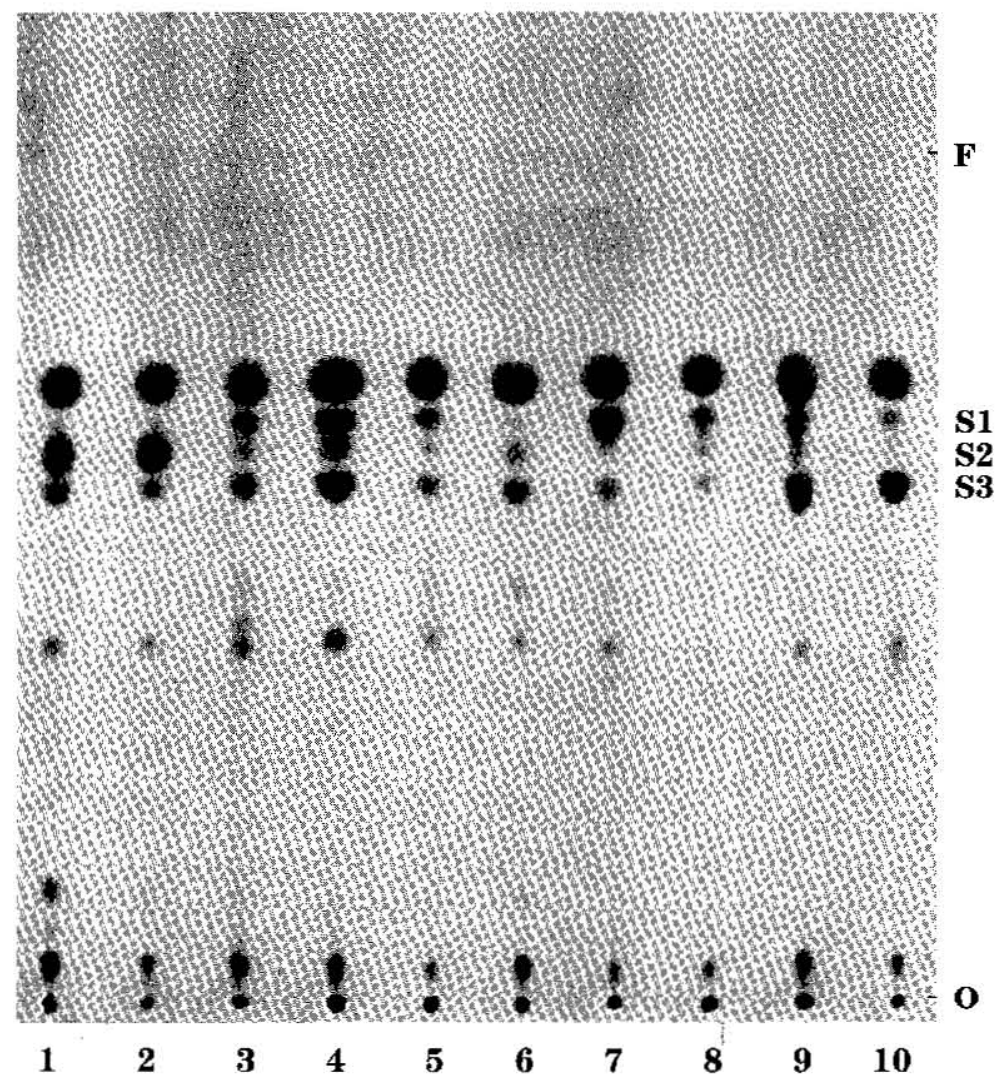

Fig. 1. TLC chromatograms of lipids from Burkholderia spp

Lanes $1, B$. caryophylli ATCC $25418^{\mathrm{r}} ; 2, B$. caryophylli NIAS 1406 ; 3, B. gladioli pv. gladioli A'TCC $10248^{1} ; 4$, B. gladioli pv. gladioli MAFF $302515 ; 5, B$. glumae MAFF $301169^{\mathrm{r}} ; 6, B$, glumae N 7501; 7 , B. cepacia ATCC $25416^{\top} ; 8, B$ cepacia $356-5 ; 9, B$. plantarii MAFF $301723^{\top} ; 10$, B. vandii JCM $7957^{\mathrm{T}}$.

$\mathrm{F}$ : Solvent front, $\mathrm{O}$ : Origin; $\mathrm{S}_{1}, \mathrm{~S}_{2}$ and $\mathrm{S}_{8}$ indicate the benchmark spots. 


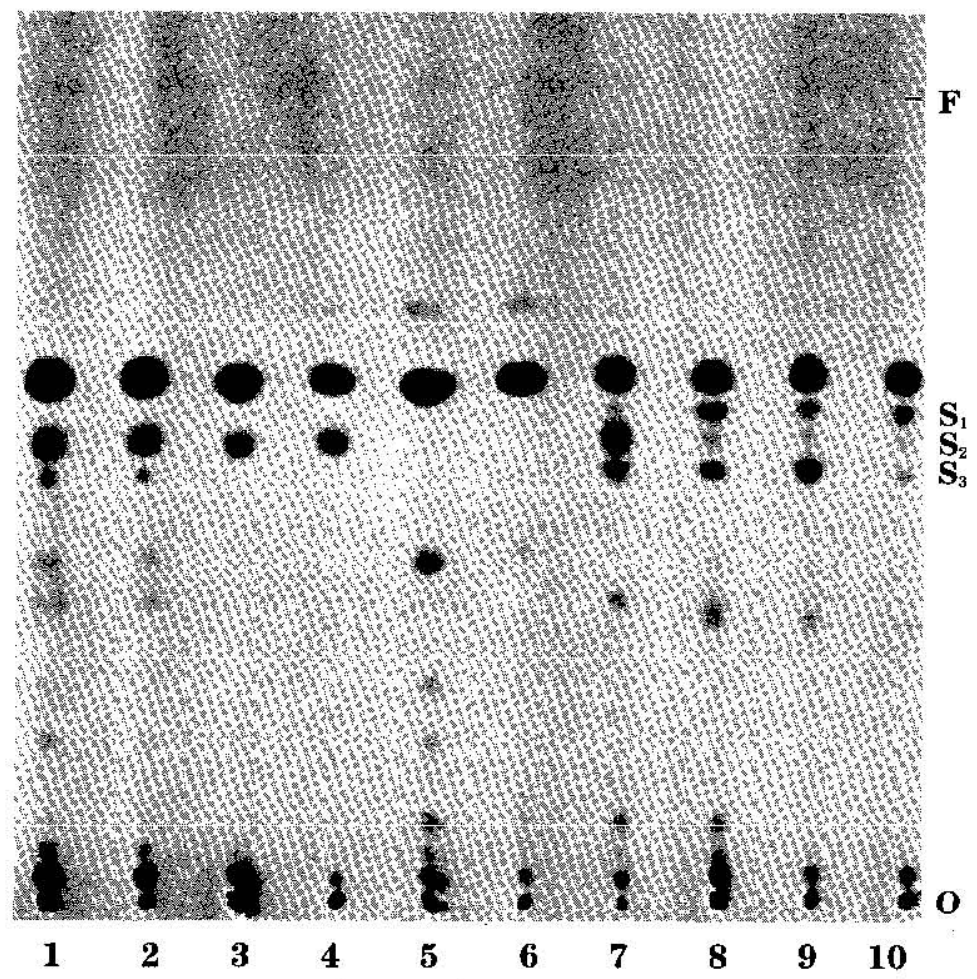

Fig. 2. TLC chromatograms of lipids from Burkholderia spp., $R$. solanacearum and $H$. rubrisubalbicans.

Lanes $1, B$. andropogonis MAFF $301006 ; 2, B$. andropogonis MAFF $301129 ; 3$, R. solanaceamum ATCC $11696^{\top} ; 4, R$. solanaceamu $\mathrm{Ku}$ $7502-1 ; 5, H$. rubrisubalbicans MAFF $301626 ; 6$, H. mibrisubalbicans MAFF 301628; 7, B. caryophylli ATCC $25418^{\mathrm{T}} ; 8, B$. gladioli pv. gladioli ATCC $10248^{\mathrm{T}} ; 9$, B. plantarii MAFF $301723^{\mathrm{T}} ; 10, B$. cepacia ATCC 25416 .

F: Solvenl front, $\mathrm{O}$ : Origin; $\mathrm{S}_{1}, \mathrm{~S}_{2}$ and $\mathrm{S}_{3}$ indicate the benchmark spots. 


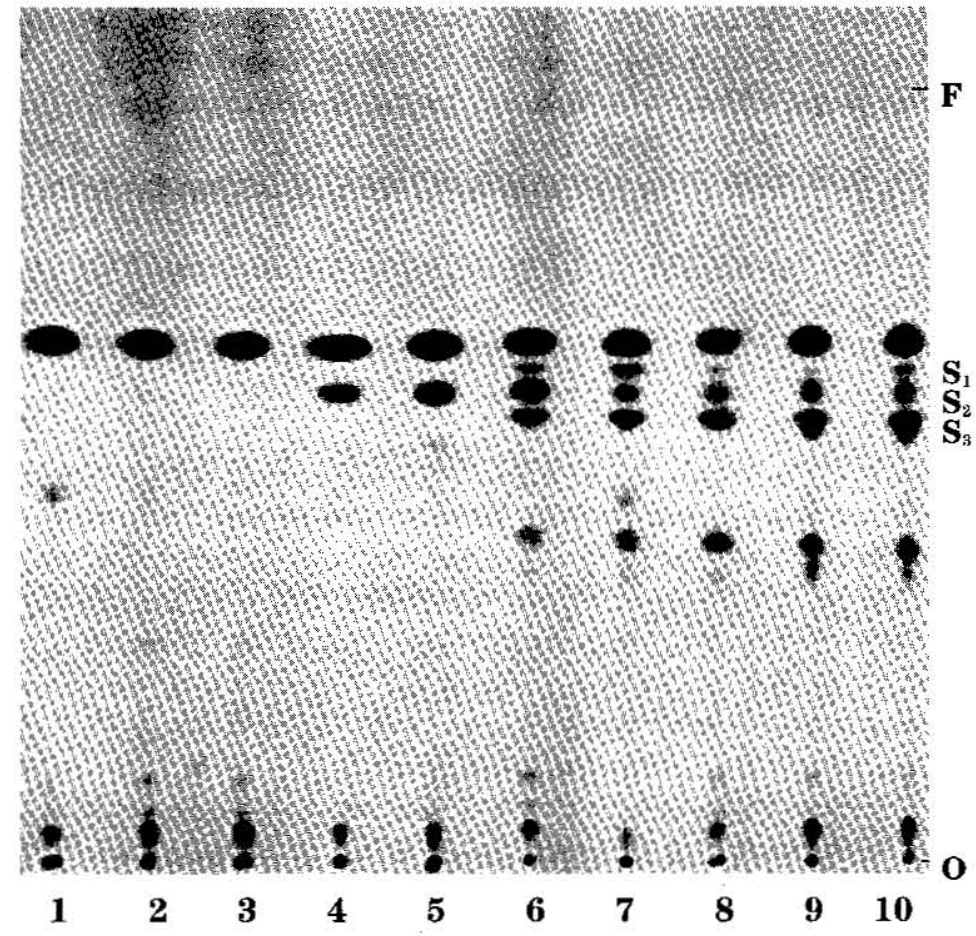

Fig. 3. TLC chromatograms of lipids from $P$. syringae, $R$. solanacearum and Burkholderia spp.

Lanes $1, P$. syringae pv. syringae ATCC $19310^{\uparrow} ; 2, P$. syringae pv. phaseolicola MAFF $301616 ; 3, P$. syringae pv. tomato MAFF 301593 ; 4, R. solanacearum ATCC $11696^{\mathrm{T}} ; 5, R$. solanacearum C $319 ; 6, B$. caryophylli MAFF $301060 ; 7, B$. gladioli pv. gladioli MAFF 301580 ; 8, B. glumae Ku 8112; 9, B. plantarii MAFF $302412 ; 10$, B. plantariz MAFF 302470 .

F: Solvent front, $O$ : Origin; $S_{1}, S_{2}$ and $S_{1}$ indicate the benehmark spots. 


\section{DISCUSSION}

Rapid and easy identification methods for phytopathogenic bacteria have been sought for some time. PCR-based molecular methods (Jensen et al., 1993; Bereswill et al., 1994; Manceau and Horvais, 1997) and chemotaxonomic markers like fatty acid profiles (Ikemoto et al., 1978; De Boer and Sasser, 1986; Roy, 1988; Chase et al., 1992; Kori et al., 1992; Stead, 1992) and protein profiles (Van Zyl and Steyn, 1990; Li and Hayward, 1994) have been used for the rapid identification of phytopathogenic bacteria. A stable marker is needed for identification and classification of different groups of bacteria. Though the lipid profiles have not been used routinely in bacterial identification, extensive studies have shown their potential as taxonomic markers (Counsell and Murray, 1986; Matsuyama et al., 1987). The direct colony TLC method for rapid detection and identification of bacterial lipids was developed and used for the identification of Serratia spp. (Matsuyama et al., 1986, 1987). The rapid identification of phytopathogenic bacteria by using this direct colony TLC has also been reported (Matsuyama et al., 1993a; Matsuyama and Furuya, 1993b; Matsuyana, 1995). Recertly, we used the simple TLC method for the identification of phytopathogenic bacteria (Khan and Matsuyama, 1998). However, both the direct colony TLC and the simple TLC methods need $1-2 \mathrm{~h}$ for drying the bacterial colony/lipid spot on the TLC plate before developments. This constraint is possible to overcome by our present method. Hence this method is less time consuming and easy to perform.

The taxonomic utility of lipid profiles requires reasonable uniformity within the group. The lipid profiles of strains of each species used in this experiment showed obviously uniformity within the species and distinguishable from the member of other species on the basis of three benchmark spots $\left(S_{1}, S_{2}\right.$ and $\left.S_{3}\right)$ appeared on TLC plate under the common spot at Rf 0.76 (Figs. 1,2 and 3). The results of our present method agreed well with the former results by the direct colony TLC and simple TLC (Matsuyama and Furuya, 1993b; Matsuyama, 1995; Khan and Matsuyama, 1998). Lipid spots appeared at Rf $0.42-0.52$ were also important benchmarks for some strains and these spots were not detectable by the original direct colony TLC method (Matsuyama and Furuya, 1993b; Matsuyama, 1995). The chromatograms of the most members of Burkholderia such as B. caryophyili, B. cepacia, B. gladioli, B. giumae, B. plantarii and B. vanaii resembled each other by lipid profiles but were clearly distinct from those of other strains which were also members of rRNA homology group-II pseudomonads; which justified the proposal of shifting $P$. caryophylli, $P$. cepacia, $P$. gladioli, $P$. glumae and $P$. plantarii into the new genus Burkholderia (Yabuuchi et al., 1992; Urakami et al., 1994). The chromatograms of $R$. solanacearum ( $P$. solanaceamum) were roughly similar to those of $B$. andropogonis but quite different from other Burkholderia spp. The lipid profile of H. rubrisubalbicans ( $P$. rubrisubalbicans) was quite unique. In case of $P$. syringae pathovars, only the common spot at Rf 0.76 was observed. Fatty acid profiles of $P$. syringae pathovars also differentiated them from rRNA homology group II pseudomonads. Again $H$. rubrisubalbicans and $R$. solanacearum were also discriminated from other members of rRNA homology group II pseudomonads on the basis of hydroxy fatty acid composition (Stead, 1992; Young et al., 1992). These results were also supported by the findings of our TLC methods. The substances visualized by ninhydrin 
spray perhaps aminolipids, characterization of lipids is subject for others.

This rapid extraction-TLC method will be practical and convenient for rapid differentiation as well as identification of Burkholderia spp., $R$. solanacearum, $H$. rubrisubalbicans and $P$. syringae pathovars.

\section{REFERENCES}

Bereswill, S., P. Bugert, B. Volksch, M. Ullrich, C. L. Bender and K. Geider 1994 Identification and relatedness of coronatine-producing Pseudomonas syringae pathovars by $\mathrm{PCR}$ analysis and sequence determination of the amplification products. Appl. Environ. Microbiol, 60: $2924-2930$

Chase, A. R., R. E. Stall, N. C. Hodge and J. B. Jones 1992 Characterization of Xanthomonas campestris strains from aroids using physiological, pathological and fatty acid analyses. Phytopathology, 82: $754-759$

Counsell, T. J. and R. G. E. Murray 1986 Polar lipid profiles of the genus Deinococcus. Int. J. Syst. Bacteriol., 36: $202 \cdots 206$

De Boer, S. H. and H. Sasser 1986 Differentiation of Envinia carotovora subsp. carotovora and $E$. carotovora subsp. atroseptica on the basis of cellular falty acid composition. Can. J. Microbiol., 32: $796-800$

Ikemoto, S., H. Kuraishi, K. Komagata, R. Azıma, T. Suto and H. Muraoka 1978 Cellular fatty acid composition in Pseudomonas species. J. Gen. Appl. Microbiol, 24: 199-213

Jensen, M. A., J. A. Webster and N. Straus 1993 Rapid identification of bacteria on the basis of pulynerast tìlain reaciion-anplified ribosomal DNA spacer polymorphisms. Appl. Environ. Microbiol., $\mathbf{5 9}$ : $945-952$

Khan, A. A. and N. Matsuyama 1998 Rapid identification of phytopathogenic bacteria by TLC. J. Fac. Agr., Kyushu Lniv., 42: 281-287

Kori, Y., N. Furuya, K. Tsuno and N. Matsuyama 1992 Differentiation of Erwinia chrysanthemi and E. carolowora subsp. carolowora by cellular laily acii analysis. d. Fac. Agr, Kyushu Univ., 37: 173-178

Li, X. and A. C. Hayward 1994 Bacterial whole cell protein profiles of the rRNA group II pseudomonads. J. Appl. Bacteriol., 77: 308-318

Manceau, C. and A. Horvais 1997 Assessment of genetic diversity among strains of Pseudomonas syringae by PCR - resiriction fragmeni lengih polymorphism andysis of rRNA operons with special emphasis on P. syringae pv. tomato. Appl. Environ. Microbiol. 63: 498-505

Matsuyama, N., I. H. Mian, A. M. Akanda and N. Furuya 1993a Comparative studies on thin-layer chromatograms of lipids from various phytopathogenic bacteria. Ann. Phytopath. Soc. Japan, 59: $528-534$

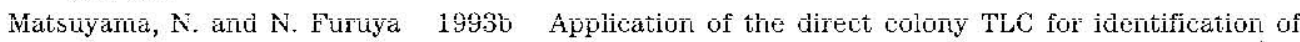
phytopathogenic bacteria (II) Chromatographic profile of Erwinia and Pseudomomas spp. J. Fac. Agr., Kyushu Univ., 38: 89-95

Matsuyama, N. 1995 Application of the direct colony TLC for identification of phytopathogenic bacteria (III). Distinction of the pseudomonads in the rRNA- homology group II (Burkholderia spp.). J. Fac. Agr., Kyushu Univ., 4: 189-196

Matsuyama, T., M. Sogawa, K. Kaneda and I. Yano 1986 Rapid detection and identification of bacterial lipids by direct colony thin-layer chromatography. Proc. 29rd Int. Symp. Adv. Chrom. Chiba, Japan, pp 127-128

Matsuyama, T., M. Sogawa and I. Yano 1987 [jirect colony thin-layer chromatography and rapid characterization of Serratia marcescens mutants defective in production of wetting agents. Appl. Environ. Microbiol., 53: $1186-1188$

Pecknold, P. C. and R. G. Grogan 1973 Deoxyribonucleic acid homology groups among phytopathogenic Pseudomonas species. Int. J. Syst. Bacteriol, 23: 111-121

Roy, M. A. 1988 Use of fatty acids for the identification of phytopathogenic bacteria. Plant Disease, 72: 460

Stead, D. E. 1992 Grouping of plant-pathogenic and some other Pseudomonas spp. by using cellular fatty acid profiles. Int. J. Syst. Bacteriol., 42: 281-295 
Urakami, T., C. Ito-Yoshida, H. Araki, T. Kajima, K. Suzuki and K. Komagata 1994 Transfer of Pseudomonas plantarii and Pseudomonas glumae to Burkholderia as Burkholderia spp. and description of Burkholderia vandii sp. nov. Int. J Syst. Bacteriol., 44: 235-245

Van Zyl, E. and P. L. Steyn 1990 Differentiation of phytopathogenic Pseudomonas and Xanthomonas species and pathovars by numerical taxonomy and protein gel electrophoregrams. Sys. Appl. Microbiol., 13: $60-71$

Yabuuchi, E., Y. Kosako, H. Oyaizu, I. Yano, H. Hotta, Y. Hashimoto, T. Ezaki and M. Arakawa 1992 Proposal of Burkholderia gen. nov. and transfer of seven species of the genus Pseudomonas homology group II to the new genus, with the type species Burkholderia cepacia (Palleroni and Holmes, 1981) comb. nov. Microbiol. Immunol., 36: 1251-1275

Young, J. M., Y. Takikawa, L. Garden and D. E. Stead 1992 Changing concepts in the taxonomy of plant pathogenic bacteria. Annu. Rev. Phytopathol, 30: 67-105 